\title{
A ERA MEIJI NOS TEXTOS DE EÇA DE QUEIRÓS
}

\section{José Carvalho Vanzelli ${ }^{1}$}

Resumo: Embora seja mais conhecido como um dos principais romancistas lusófonos, Eça de Queirós (1845-1900) também foi um profícuo jornalista, escrevendo desde os anos 60 do século XIX até o final de sua vida em diversos periódicos portugueses, brasileiros e franceses. Apesar de nunca ter visitado o Japão, o autor de Os Maias dedicou alguns textos (ou partes de textos) à sociedade de Meiji. Neste trabalho intencionamos examinar como o afamado escritor português representou a "Terra do Sol Nascente" a seu público, verificando se existe um discurso consonante ou dissonante com a estética japonista que vigorou no fin-de-siècle europeu.

Palavras-chave: Japão; Eça de Queirós; Orientalismo Literário; Japonismo; Século XIX.

Abstract: Best known as one of the major Lusophone novelists, Eça de Queirós (1845-1900) was also a prolific journalist. He wrote since the 60 s of the nineteenth century to the end of his life in various Portuguese, Brazilian and French journals. Although he never visited Japan, the author of Os Maias dedicated some texts (or parts of texts) to the Meiji society. In this article we intend to examine how the famous Portuguese writer represented the "Land of the Rising Sun" to his readers, verifying if there is a consonant or dissonant discourse with the Japonistic aesthetics, present in Europe's fin-de-siècle.

Keywords: Japan; Eça de Queirós; Literary Orientalism; Japonism; $19^{\text {th }}$ Century.

1. Mestre em Letras, na área de Estudos Comparados de Literaturas de Línguas Portuguesa pela Faculdade de Filosofia, Letras e Ciências Humanas da Universidade de São Paulo (FFLCH-USP) com a pesquisa "Eça de Queirós e o Extremo Oriente". Graduado em Letras (Português- Japonês) pela Universidade de São Paulo (USP). Professor do Departamento de Estudos Brasileiros da Hankuk University of Foreign Studies (HUFS), Coreia do Sul; jcvanzelli@yahoo.com.br. 


\section{O Japão da era Meiji expresso em língua portuguesa}

O mais famoso investigador da identidade portuguesa de nossos tempos, Eduardo Lourenço, ao descrever Portugal de meados do século XIX, em seu igualmente afamado ensaio "Da literatura como interpretação de Portugal", diz:

Um Portugal timidamente aberto à industrialização e aberto um pouco como se fôssemos o Japão da Europa no mesmo momento violado sem contemplações pelo Oncle Sam [...] vê-se num ápice confundido com uma avalancha cultural que de modo algum pode digerir em termos, digamos, aceitáveis (LOURENÇO, 2009, p. 90).

Enxergar Portugal como "o Japão da Europa" parte, principalmente, das semelhanças encontradas por essas duas nações na metade dos Oitocentos. De um lado temos Portugal, um país sobretudo agrário, em grande descompasso intelectual e tecnológico com o restante do continente europeu que se vê - também graças a um grupo de jovens intelectuais, posteriormente conhecido como Geração de 70, composto por figuras importantes da literatura lusa como Antero de Quental, Eça de Queirós, entre outros - invadido por inúmeras correntes e tendências artísticas e filosóficas vindas da França, da Inglaterra e Alemanha. De outro, encontramos o Japão, que, com a chegada do Comodoro Perry à costa de Edo em 1853, é obrigado a abrir seus portos ao comércio com Estados Unidos e Europa, recebendo, também, uma grande quantidade de ideias e conhecimento científico que causaram a veloz modernização japonesa durante o período Meiji (1868-1912).

Este olhar, no entanto, nos revela mais do que o momento histórico de cada nação. Retoma, mesmo que involuntariamente, uma relação que vem desde o século XVI, quando navegadores lusitanos aportaram, em 1543, na ilha de Tanegashima, na atual província de Kagoshima. Com a proibição do livre trânsito de estrangeiros no território japonês e o período de "isolamento" conhecido na história japonesa como sakoku jidai (16391854) - espaço de tempo que compreende quase todo o período Edo (1600-1868) - houve, obviamente, uma cessão nas relações internacionais não apenas entre lusitanos e nipônicos, mas entre japoneses e praticamente todas as nações europeias. Ao se restabelecer as relações entre Portugal e Japão, em 1860, o mundo já havia mudado e Portugal já não gozava de um protagonismo político-econômico como em meados do século XVI. Entretanto, isto não evitou que intercâmbios culturais ocorressem principalmente de portugueses que, a exemplo de outros europeus, visitaram ou se instalaram no Japão.

Para deixarmos este ponto mais claro, é importante lembrar que, a partir da retomada das relações internacionais oficiais entre o Japão e outras nações em $1854^{2}$ e com a restauração do poder imperial ocorrida no Japão em 1868, não foram poucos os

2. Como dissemos, as relações Portugal-Japão foram retomadas em 1860. Já com o Brasil, o Japão estabeleceu relações a partir de 1895 . 
diplomatas, oficiais da marinha e artistas europeus e americanos que procuraram descrever - alguns com louvor, outros com horror - a sociedade japonesa, que neste período já se transformava. Os mais de duzentos anos de isolamento cultural, que contribuíram para moldar aspectos da cultura japonesa que hoje denominamos "tradicional", fizeram do Japão um "prato cheio" para intelectuais ocidentais em busca de novas culturas, religiões e modos de vida. Assim, como tendência dos últimos trinta anos de século XIX, abundam descrições de viagens, paisagens ou reconstruções históricas feitas por viajantes que por algum período estiveram ou que se fixaram definitivamente no Japão. Nas palavras de Luiz Dantas:

\begin{abstract}
Escrever sobre o Japão no final do século XIX implicava aderir a uma tendência artística, a um gosto, cuja primeira característica era a de ser cosmopolita. Europeus e americanos do norte e do sul, homens de letras ou artistas plásticos, o público cultivado em geral, achavam-se sensibilizados, fascinados, pela última grande descoberta do Ocidente, [...] o Japão.

[...] O Japão oferecia a esses homens de letras condições excepcionais de interesse: a distância, um período longo de isolamento, uma civilização e um passado prestigiosos. E valor suplementar: a modernização acelerada do país tornava-o aos olhos ocidentais um espetáculo único, porque efêmero. (DANTAS, 2010, p. 185-189)
\end{abstract}

Deste modo, a paisagem, as artes e a estética japonesa começaram a influenciar as produções artísticas europeias, não tardando para que o termo "japonismo" fosse criado.

São inúmeros os exemplos que podemos nos remeter para ilustrar esse movimento. Restringindo-nos apenas a alguns dos mais famosos, encontramos, no campo das artes plásticas, os quadros impressionistas Madame Monet en costume japonaise ou Lajaponaise (1875) de Claude Monet (1840-1926), Émile Zola (1868) de Edouard Manet (1832-1883), ou ainda a admiração de Van Gogh (1853-1890) pelas estampas japonesas³; na música, a ópera cómica The Mikado ou The Town of Titipu (1885) dos ingleses Arthur Sullivan (1842-1900) e W. S. Gilbert (1836-1911) e a ópera dramática Madama Butterfly (1906) de Giacomo Puccini (1858-1924); e na literatura, as obras de Pierre Loti (1850-1923), a se destacar Madame Chrysanthème (1887), os escritos de Edmond Goncourt (1822-1896) ou os diversos livros do grego naturalizado japonês Lafcadio Hearn (1850-1904)4.

Ainda no campo da literatura, mas agora focando-nos ao que foi produzido em língua portuguesa, também encontramos inúmeros escritos, principalmente obras que se encaixam dentro do gênero de literatura de viagens. Estes textos foram elaborados, em sua maioria, por membros da marinha ou diplomatas. De acordo

3. O Museu Van Gogh, em Amsterdã, possui uma sala dedicada exclusivamente ao acervo de estampas e pinturas japonistas de Van Gogh.

4. Cf. lista de obras de cada um desses três escritores feita por Luiz Dantas (2010, p. 190-191). Este estudioso também cita o jurista francês Georges Bousquet (1845-1937) como um escritor "japonista", ao se referir ao livro Le Japon de nos jours (1877 - “O Japão de nossos dias”, em tradução livre). 
com inúmeros levantamentos apresentados em estudos portugueses e brasileiros ${ }^{5}$, no último quartel do século XIX e nas primeiras décadas do século XX, foram feitas as seguintes obras: em Portugal, Viagem da Corveta D. João I à Capital do Japão no ano de 1860 (1863), escrito por Feliciano Antônio Marques Pereira (1839-1881), O Japão - Estudos e Impressões de Viagens (1873) de Pedro Gastão Mesnier (1846-1888), Japão por dentro (1904) de Landislau Batalha (1856-1939) e Apontamentos dos Progressos do Japão, durante os últimos quarenta anos (1914) de Felix Ribeiro (18??-19??), além de outros textos de Polidoro Francisco da Silva, Gonçalves Pereira ou José Augusto Correia; e, no Brasil ${ }^{6}$, Memórias de um cônsul no Japão (1902) de Jacinto Ferreira da Cunha, No Japão (1903) de Oliveira Lima (1867-1928) e Samurais e Mandarins (1912) de Luiz Guimarães Filho (18781940). No campo da ficção, pode-se destacar ainda o livro A Estrela de Nagasáqui (1907) do português António de Campos Júnior (1850-1917).

Aluísio Azevedo (1857-1913), um dos principais nomes da literatura naturalista no Brasil e vice-cônsul do Brasil em Yokohama entre os anos de 1897 e 1898, também começou a redigir um livro sobre o Japão. Este texto, intitulado $O$

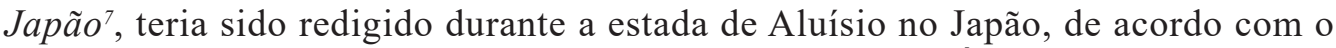
manuscrito encontrado na Academia Brasileira de Letras. É constituído por cinco capítulos em que se reconstrói a história japonesa desde uma origem lendária até a era Meiji, acrescentando opiniões e sua visão particular de alguns assuntos. Acredita-se que esta obra está incompleta (LIMA, 2010, p. 16 e DANTAS, 2010, p. 216), pois se imagina que Aluísio Azevedo ainda discorreria detalhadamente sobre aspectos da sociedade de Meiji nas páginas seguintes. O autor de $O$ Cortiço não publicou este texto em vida. O grande número de obras que "desvendavam" o Japão ao público lusófono - tirando, assim, o ineditismo de seu texto - e problemas financeiros (LIMA, 2010, p. 16-18), seriam os principais motivos de nunca ter levado seu livro ao grande público. Esta obra, no entanto, foi publicada quase um século depois, em 1984, graças aos esforços de Luiz Dantas.

No entanto, ao falarmos do Japão descrito em língua portuguesa, o nome que mais

5. Cf. FIGUEIREDO, 1993, p. 26-28; CASTELO-BRANCO, 2004, p. 77; ARAÚJO, 2008, p. 15 e LIMA, 2010, p.18.

6. No caso do Brasil, não se pode esquecer que a imigração japonesa foi iniciada em 1908, influenciando de maneira direta a relação do Japão, sua poesia e seus escritos com a literatura brasileira. Não aprofundaremos esta questão, pois nosso foco está em um autor lusitano. Entretanto, para um estudo mais cuidadoso sobre a influência do Japão e do japonismo na literatura brasileira, cf. KUNIYOSHI, 1998, p. 93-114.

7. Luiz Dantas (2010, p. 215-216) esclarece que "O Japão" é como o texto está identificado no manuscrito da Biblioteca Nacional e, por isso, foi conservado como título em sua publicação. Entretanto, se depreende da correspondência de Azevedo que talvez este não seja o título definitivo escolhido pelo autor, sendo citado outras possibilidades como "Agonia de uma raça" ou "O Japão tal como é". 
se destaca é, sem dúvida, o de Wenceslau de Moraes (1854-1929). Inicialmente oficial da marinha portuguesa, Wenceslau entrou em contato com o Japão na última década do século XIX, se instalando no país em 1898, onde exerceu funções diplomáticas em Kobe até o ano de 1913. Neste ano se mudou para a cidade de Tokushima, local em que residiu até sua morte. O Japão se fez presente em todas as obras escritas pelo autor, desde suas primeiras impressões da Ásia, descritas em Traços do Extremo Oriente (1895), até sua última obra Relance da alma japonesa (1929). Foram produzidos, neste intervalo, inúmeros escritos versando quase que exclusivamente sobre o Japão, sua história, sua cultura, sua gente e seu modo de vida. A identificação com o Japão e sua cultura foi tão forte que não é raro encontrarmos referência a Wenceslau de Moraes como um autor que se "orientalizou" ou se "japonizou". No entanto, parece-nos que o caso de Wenceslau se trata mais de uma assimilação ímpar da cultura do país em que viveu por mais de trinta anos sem abdicar de sua posição de europeu e português do que uma "troca de alma", conforme propõe Fidelino de Figueiredo (1993, p. 37). Uma leitura comparativa dos primeiros escritos de Wenceslau sobre o Japão com os textos da década de 20 do século XX, deixa claro como o ex-oficial da marinha portuguesa passa de uma visão poeticamente fascinada e, também por isso, eurocêntrica a uma visão mais analítica, neutra e problematizadora. Ou, nas palavras de Érika Horigoshi:

[...] a visão expressa por Moraes em Dai Nippon [de 1895] é uma visão inicialmente construída pelo saber ocidental e encaixa-se na perspectiva orientalista de Said, na medida em que revela mais sobre o observador do que sobre o observado, reproduzindo estereótipos e tomando uma postura superior em relação ao seu assunto. [...] O exercício de alteridade executado por Wenceslau de Moraes vai, no entanto, mudando de característica à medida que muda também o caráter do contato que o escritor português estabelece com o Japão. Quando Moraes passa da observação para a interação, o tom de suas análises também vai se modificando e se refletindo em seus textos. É quando os seus escritos começam a problematizar aquilo que vê na sociedade japonesa. Isso é demonstrado sobretudo em suas última obras, escritas já na fase em que o autor viveu solitariamente em Tokushima. [...] Em sua fase final [...] Wenceslau de Moraes mostra uma postura orientalista mais próxima da definição de Aijaz Ahmad, um orientalismo positivo, que valoriza sobremaneira seu tema de estudo, em contraposição à atitude depreciativa em relação ao Oriente, esta apontada por ele como "anglicizadora". (HORIGOSHI, 2012, p. 82-84).

Ao ver impressões gerais de Aluísio Azevedo e Wenceslau de Moraes nos seus primeiros contatos com o Japão, nota-se em comum uma admiração pelo Japão de Edo, por um "Japão japonês", lamentando a acelerada modernização e a rápida 
assimilação de conceitos euro-americanos que o Japão desenvolveu neste período. Tais posicionamentos não são raros de serem encontrados em textos de intelectuais desta época. Mesmo aqueles que não conheceram o Japão, muitas vezes lamentavam a crescente globalização no Oriente, tendo a tecnologia euro-americana como padrão a ser seguido. É de se lembrar que, em muito dos casos, a adoção de tal tecnologia foi parte da imposição das potências ocidentais como parte da política colonialista e imperialista na Ásia. No entanto, o desejo da preservação de uma cultura "pura" oriental não deixa de figurar entre um dos lugares-comuns expostos por muitos intelectuais dessa época.

\section{Eça e o Japão}

Em nossa breve reconstrução do Japão e do "japonismo" no ambiente artístico europeu e lusófono, não citamos o autor central deste trabalho, o renomado romancista português, Eça de Queirós (1845-1900). Até mesmo para especialistas na obra queirosiana, tratar da relação entre o autor de O Primo Basílio e o Japão pode causar estranheza, uma vez que Eça nunca visitou o Japão, nunca transportou nenhuma de suas personagens ao Japão, ou criou uma personagem nipônica. Ou seja, não há nada que ligue, num primeiro momento, este autor português à Terra do Sol Nascente. Em sua ficção as referências ao Japão são, em sua maioria, furtivas. A primeira delas acontece em seu primeiro romance, $O$ Crime do Padre Amaro, que teve sua primeira versão publicada em 1875 na Revista Occidental e sua versão definitiva finalizada em 1880. No capítulo XXI desta obra é feita rápida menção a S. Francisco Xavier, conhecido também como "Apóstolo do Oriente", um dos fundadores da Companhia de Jesus, que foi missionário em diversos pontos do Oriente, entre eles o Japão. No parágrafo seguinte, mais uma vez se comenta sobre missionários em território japonês, sem que, contudo, se desenhe uma imagem mais trabalhada da "Terra do Sol Nascente". Ainda, em diversas outras obras, como O Mistério da Estrada de Sintra (1870) - escrito a quatro mãos com Ramalho Ortigão - ou A Cidade e as Serras (1901), aparecem referências a objetos oriundos de território nipônico, mostrando como a estética do japonismo estava em voga na decoração de interiores do fin-de-siècle.

De todo o conjunto de obras ficcionais de Eça, as principais referências se encontram no afamado romance Os Maias (1888). Lá também existem menções furtivas a objetos de origem nipônica como vasos, biombos, faianças ou louças, demonstrando, novamente, a "japonoiserie" na decoração de interiores da época. No entanto, neste mesmo romance encontramos duas referências mais expressivas. A primeira alude ao local de encontro de dois dos protagonistas do romance: Maria Eduarda e Carlos da Maia. No capítulo 14, é dito:

Davam duas horas; e começavam logo nos quartos de cima as longas lições de Rosa. Carlos e Maria iam então refugiar-se numa intimidade mais livre, no quiosque japonês, que uma fantasia de Craft, o seu amor do Japão, construíra ao pé da rua de acácias, aproveitando a 
sombra e o retiro bucólico de dois velhos castanheiros. Maria afeiçoara-se àquele recanto, chamava-lhe o seu pensadouro. Era todo de madeira, com uma só janelinha redonda, e um telhado agudo à japonesa, onde roçavam os ramos - tão leve que através dele nos momentos de silêncio se sentiam piar as aves. Craft forrara-o todo de esteiras finas da Índia; uma mesa de charão, algumas faianças do Japão, ornavam-no sobriamente; o teto não se via, oculto por uma colcha de seda amarela, suspensa pelos quatro cantos, em laços, como o rico dossel de uma tenda; - e todo o ligeiro quiosque parecia ter sido armado só com o fim de abrigar um divã baixo e fofo, duma languidez de serralho, profundo para todos os sonhos, amplo para todas as preguiças... (QUEIRÓS, 1958, vol. 2, p. 315-316)

Já a segunda, um pouco mais extensa, está nos primeiros parágrafos do capítulo 18, quando é feita referência a uma viagem ao Japão por Carlos e seu amigo João da Ega. Cito:

Semanas depois, nos primeiros dias de ano novo, a Gazeta Ilustrada trazia na sua coluna do High-life esta noticia: "O distinto e brilhante sportsman, o Sr. Carlos da Maia, e o nosso amigo e colaborador João da Ega, partiram ontem para Londres, de onde seguirão em breve para a América do Norte, devendo daí prolongar a sua interessante viagem até ao Japão. Numerosos amigos foram a bordo do Tamar despedir-se dos simpáticos touristes. Vimos entre outros os Srs. ministro da Finlândia e seu secretario, o marquês de Souzela, conde de Gouvarinho, visconde de Darque, Guilherme Craft, Teles da Gama, Cruges, Taveira, Vilaça, general Sequeira, o glorioso poeta Tomás de Alencar, etc. etc. O nosso amigo e colaborador João da Ega fez-nos, no último shake-hands, a promessa de nos mandar algumas cartas com as suas impressões do Japão, esse delicioso país de onde nos vem o sol e a moda! É uma boa nova para todos os que prezam a observação e o espírito. Au revoir!"

$[\ldots]$

Mas, passado ano e meio, num lindo dia de março, Ega reapareceu no Chiado. E foi uma sensação! Vinha esplêndido, mais forte, mais trigueiro, soberbo de verve, num alto apuro de toilete, cheio de histórias e de aventuras do Oriente, não tolerando nada em arte ou poesia que não fosse do Japão ou da China, e anunciando um grande livro, o "seu livro", sob este título grave de crónica heróica - Jornadas da Ásia (QUEIRÓS, 1958, vol. 2, p. 476-477).

Por estas passagens, notam-se alguns dos pontos anteriormente assinalados por nós. Isto é, verifica-se a presença da estética do japonismo não apenas na arquitetura e decoração, como na aristocracia europeia de um modo geral, sendo a terra do imperador Meiji definida como "o país da moda"; vê-se a tendência literária da literatura de viagens, com referência ao desejo de Ega de escrever o "seu livro" de "Jornadas da Ásia"; ou o gosto pelas artes japonesas (e chinesas), quando é dito que João da Ega não tolerava "nada em arte ou poesia que não fosse do Japão e da China". Assim, neste trecho, verificam-se as várias formas em que o "japonismo" fez-se presente na sociedade burguesa da Europa nesta época.

Embora estes trechos sirvam como exemplos claros do olhar de Eça, que enxergava com nitidez o momento do "japonismo" e a grande presença da temática 
inspirada pelo Japão na sociedade europeia finissecular, ainda é pouco para traçarmos um Japão queirosiano. Recorremos, então, aos seus textos de imprensa, principalmente às crônicas escritas na década de 90 do século XIX.

Para além de seu trabalho enquanto romancista, Eça também foi um profícuo jornalista ${ }^{8}$, escrevendo artigos de assuntos diversos para jornais e revistas de Portugal, França e Brasil. O jornal Gazeta de Notícias do Rio de Janeiro publicou algumas das mais importantes crônicas que Eça escreveu. Eça trabalhou como correspondente internacional para este periódico em dois períodos: um primeiro que vai de 1880 a 1882, quando exercia a função de correspondente na Inglaterra, onde exerceu também a função de cônsul português nas cidades de Newcastle e Bristol'; e um segundo que vai de 1892 a 1897, quando já trabalhava como cônsul de Portugal em Paris (MINÉ, 2000, p. 18-19). É neste segundo momento de contribuição ao jornal carioca que as principais reflexões queirosianas sobre o Oriente foram divulgadas. Consequentemente, nos artigos deste período, estão suas principais reflexões sobre a "Terra do Sol Nascente".

Percorramos, então, alguns artigos, para verificarmos como o Japão surge no jornalismo queirosiano.

A principal crônica queirosiana que versa sobre o Oriente foi publicada na Gazeta de Notícias entre os dias 1 e 6 de dezembro de 1894 na "seção habitual do autor que em 1893 mudou de Ecos de Paris para Cartas Familiares de Paris. Como subtítulo temático apareceu 'Os chineses e os japoneses"” (GROSSEGESSE, 1997, p. 21). Quando parte integrante dos livros de crônicas de Eça publicados postumamente, este texto surge com o título de "Chineses e Japoneses", nome que manteremos aqui neste estudo.

Esta crônica tem por principal objetivo discutir a entrada de trabalhadores chineses no Brasil para suprir a mão de obra escrava que se tornara livre alguns anos antes. No entanto, este verdadeiro motivo só é revelado nos momentos finais da crônica. É comum na escrita jornalística queirosiana - assim como de outros escritores lusófonos da época, como Machado de Assis - iniciar e ocupar parte da crônica com outras questões próximas ao verdadeiro objetivo de seu texto. Aqui, em "Chineses e Japoneses", o ponto de partida do texto é o conflito bélico entre China e Japão, que ficou conhecido na história como $1^{\text {a }}$ Guerra Sino-Japonesa (1894-95). Ao descrever a batalha entre China e Japão pela posse da península coreana, Eça faz um retrato das três nações envolvidas no imbróglio. Inicia sua caracterização da Coreia:

A nordeste da China, ou antes da Manchúria chinesa, entre o mar do Japão e o mar Amarelo, há uma tristonha península de costas escarpadas, que a si própria se enfeitou, desde o ano de 1392, quando começou a reinar a dinastia que ainda hoje reina (ou que

8. Para estudos cuidadosos sobre Eça de Queirós enquanto jornalista, cf. MINÉ, 2000.

9. Eça trabalhou em Newcastle de 1874 a 1879 e em Bristol de 1879 a 1888. 
ainda reinava no mês, passado) com o nome risonho, luminoso e fresco de Reino da Serenidade Matutina. Os Japoneses, seus vizinhos, chamam a esta terra Ko Rai; nós, mais comodamente, Coreia. E um país tão silencioso, tão recluso, tão separado de toda a humanidade, mesmo dos seus parentes asiáticos, que no Japão e na China o designam pela alcunha de País Ermitão. O que dele, na Europa, nós melhor conhecemos, por estampas, é a figura dos seus habitantes, homens esguios e graves, de longos bigodes pendentes, que usam o mais extraordinário chapéu de que reza a história das modas, o formidável chapéu coreense, muito alto, muito pontiagudo e de abas tão vastas que sob ele um patriarca pode abrigar toda a sua descendência, os seus móveis e os seus gados. Estes homens falam um chinês mascavado de tártaro, vivem de arroz e habitam casas rudimentares, feitas de bambu, adobe e papel. (QUEIRÓS, 2002, p. 527);

Logo, mostra como os chineses eram vistos pelos europeus. Cito:

Para o Europeu, o Chinês é ainda um ratão amarelo, de olhos oblíquos, de comprido rabicho, com unhas de três polegadas, muito antiquado, muito pueril, cheio de manias caturras, exalando um aroma de sândalo e de ópio, que come vertiginosamente montanhas de arroz com dois pauzinhos e passa a vida por entre lanternas de papel, fazendo vénias. (QUEIRÓS, 2002, p. 529).

Na mesma linha de raciocínio, apresenta a seu "público duplo" (GROSSEGESSE, 1997, p. 8), isto é, portugueses e brasileiros, a visão europeia comum acerca do japonês:

E o Japonês é ainda para nós um magricela de crânio rapado, com dois enormes sabres enfiados na cintura, jovial e airado, correndo, abanando o leque, dissipando as horas fúteis pelos jardins de chá, recolhendo à casa feita de biombos e crisântemos para se cruzar numa esteira e rasgar o ventre! (QUEIRÓS, 2002, p. 529).

A primeira coisa a se notar destas caracterizações é a evidente ironia nelas presente. Eça de Queirós é bastante conhecido por sua ironia refinada, seja em seus textos jornalísticos, seja em sua ficção. Este texto é mais um exemplo claro desta característica eciana. Também, é interessante perceber que, seja na descrição dos coreanos, dos chineses ou dos japoneses, o que o autor de Os Maias faz é traçar como estes povos são enxergados pelo "europeu mediano" (QUEIRÓS, 2002, p. 529). Ou seja, já nestas primeiras linhas, nosso autor desvenda todo o estereótipo oriental presente no imaginário europeu.

Prossegue mostrando que, apesar dos estereótipos acima referidos, à grande massa ocidental todas as civilizações do Extremo-Oriente são vistas de maneira semelhantes. 
É por causa deste Reino da Serenidade Matutina [Coreia] que o Império Florido do Meio [China] está em guerra com o Império do Sol Nascente [Japão]... Assim contada desta maneira (que é a maneira oficial), a luta da China e do Japão parece um enredo de mágica, ou o começo de um desses romances alegóricos, que tanto deleitaram o século XVIII, nos tempos do Palácio Rambouillet, da boa Mademoiselle de Seudery, d'Artamène ou le Grand Cyrus. E, com efeito, para o grande público, para todos aqueles que não são profissionalmente diplomatas, sociólogos ou estratégicos, esta guerra entre as duas nações fortes do Extremo Oriente oferece apenas o interesse divertido de uma pantomima militar, passada numa região de fantasia, onde a política é dirigida pelas fardas e os príncipes são picarescos. (QUEIRÓS, 2002, p. 528).

Adiante, sempre analisando simultaneamente as civilizações chinesa e japonesa, prossegue no desmascaramento do imaginário europeu:

Mas esses povos da Extrema Ásia, por ora só os conhecemos pelos lados exteriores e excessivos do seu exotismo [...] A ambos concedemos uma habilidade hereditária em fabricar porcelana e bordar a seda. Como por vezes as suas populaças trucidam os nossos missionários, a estes traços de carácter (tão exactamente deduzidos) juntamos o da ferocidade. Porque os Chineses não querem ter caminhos de ferro, nem fios de telégrafo, nem candeeiros de gás, que constituem para nós as expressões sumas da civilização, concluímos rasgadamente que são bárbaros. E enquanto aos Japoneses, que já copiaram as locomotivas e os telefones, só nos parece que essa civilização importada, macaqueada e mal usada, os torna irreparavelmente grotescos. Que por trás do rabicho e dos guardasóis de papel, e das caturrices, e de todo o exotismo, existam sólidas instituições sociais e domésticas, uma velha e copiosa literatura, uma intensa vida moral, fecundos métodos de trabalho, energias ignoradas, o europeu mediano não o suspeita. (QUEIRÓS, 2002, p. 528-529).

Nestes trechos, vê-se claramente, a revelação da imagem europeia comum acerca do povo japonês. Assim, vê-se que a sociedade europeia finissecular, além de enxergar pitorescamente o japonês ("um magricela de crânio rapado, com dois enormes sabres enfiados na cintura, jovial e airado, correndo, abanando o leque, dissipando as horas fúteis pelos jardins de chá") não via a rápida modernização do Japão de Meiji como algo positivo. Diferentemente de alguns japonistas que viam na modernização a perda de uma cultura japonesa "pura", Eça desvenda que o olhar negativo à aquisição de tecnologia europeia se dá por este processo parecer algo "macaqueado", "mal usado" e, consequentemente "grotesco". Em outras palavras, a modernização de Meiji soava como uma espécie de "cópia mal feita" da tecnologia e dos valores europeus.

O autor de Os Maias, no entanto, mostra não compartilhar dessa visão. Aparenta ter uma visão mais positiva do que a do "europeu mediano", uma vez que parece enxergar que "por trás do rabicho e dos guarda-sóis de papel, e das caturrices, e de todo o exotismo, existam sólidas instituições sociais e domésticas, uma velha e copiosa literatura, uma intensa vida moral, fecundos métodos de trabalho". A visão positiva de Eça não ecoa, no entanto, na estética japonista. Afinal, não apresenta 
um fascínio e uma admiração pela cultura tradicional japonesa. A visão queirosiana presente neste trecho indica mais um olhar respeitoso aos nipônicos, reconhecendo que existe, de fato, uma complexa civilização muitas vezes vista com desdém por parte dos europeus, do que uma exaltação aos japoneses e suas instituições.

$\mathrm{O}$ texto prossegue com críticas semelhantes à visão europeia acerca dos povos do Extremo Oriente, se centrando principalmente na China. Assim, mostra como os europeus que vão à China não a conhecem, julgando-a pelos portos, ou seja, julgando-a superficialmente. Mostra, também, como a visão dos chineses em relação ao europeu não é mais simpática do que a dos filhos do velho continente acerca do povo do Império do Meio. Assim, uma crítica dupla, a europeus e chineses, vai se desenhando na crônica queirosiana.

A centralização de sua análise na China é bastante lógica, afinal, como dissemos, o verdadeiro objetivo do texto é discutir a entrada de imigrantes chineses no Brasil. Também é importante ressaltar que a China é a nação do Extremo Oriente em que Eça parece ter maior interesse, pois dedica maior parte de sua reflexão a esta civilização. Dizemos isto, pois vários são os textos em que a China é refletida. Como exemplo maior há a novela $O$ Mandarim, escrita em 1880, em que Eça transporta seu protagonista, Teodoro, ao Império do Meio. Acresce-se ainda o fato de, enquanto cônsul português em Havana, durante os de 1873 e 1874, Eça ter tido contato direto com uma colônia de trabalhadores chineses ${ }^{10}$. Lá, se viu obrigado a interceder perante o governo local por melhores condições de trabalho, uma vez que esses trabalhadores saíam do porto de Macau, então território português. Assim, estes imigrantes se tornavam responsabilidade da autoridade portuguesa na ilha cubana que, no caso, era Eça de Queirós.

O maior espaço da China na bibliografia queirosiana, no entanto, não representa um olhar mais simpático ao Império do Meio do que ao Japão ou às outras nações asiáticas. Uma leitura completa do texto comprova que imagem feita desta civilização é semelhante à japonesa ou, em outros textos, a de distintos territórios do Extremo Oriente.

O Japão de Meiji volta à cena em "Chineses e Japoneses". E, desta vez, uma imagem ainda mais clara de como Eça enxergava a política implementada no arquipélago japonês é apresentada. Após uma análise das relações China-Europa, criticando como cada uma enxergava a outra, nosso autor passa a simular a visão que chineses e japoneses têm entre si. Assim, chega à rivalidade política e cultural entre as duas "nações fortes do Extremo Oriente" (QUEIRÓS, 2002, p. 528). Cito:

A China, desde séculos, detesta o Japão por motivos um pouco semelhantes aos que mantêm a França e a Inglaterra num perpétuo e surdo estado de antagonismo e desestima. São as duas grandes nações do Extremo

10. Cf. MAGALHÃES, 2000 e SPENGLER, 2000. 
Oriente, onde ambas aspiram o predomínio; têm um desenvolvimento idêntico, em literatura, em arte, mesmo em certas indústrias nacionais que ambas exportam e que se chocam nos mercados, o que ajunta à emulação intelectual a emulação comercial: os seus temperamentos, além disso, são dissemelhantes como o do Francês e do Inglês, um grave e prático, outro ligeiro e fantasista, o que cria, no constante encontro dos homens das duas raças, uma multiplicidade de pequeninas antipatias individuais, que se prendem e se somam, num vasto ódio internacional. Guerras sucessivas têm intensificado essa rivalidade - e realmente o Chinês e o Japonês, que ambos mutuamente se tratam de bárbaros e de escória da Terra, só tinham tido até hoje um impedimento para se entredilacerarem, que era o mar que os separa, a insuficiência das suas marinhas e o medo comum da Europa. (QUEIRÓS, 2002, p. 536-537).

A comparação de China e Japão com França e Inglaterra - os principais centros políticos e culturais da Europa do final do século XIX - só vem a reforçar a consciência de Eça que se afasta do chamou de "europeu mediano". O autor enxerga as particularidades de cada uma das nações, além de se mostrar atualizado com questões políticas de sua contemporaneidade, fato importante para alguém que exercia a função de diplomata, além de correspondente internacional de jornais. Prossegue, então, tratando diretamente sobre o Japão.

\footnotetext{
Ora, o Japão, como todos sabem, realizou uma transformação extraordinária e decerto única na história. De uma manhã para a tarde, sem descanso, com um ardor frenético, este povo ligeiro e gárrulo sacudiu as suas tradições, as suas instituições, as suas leis, os seus costumes, os seus trajes, as suas maneiras - e envergou de uma só vez, e toda completa, como uma farpela, a civilização europeia, comprada por preços ruinosos num "armazém de civilizações feitas" (QUEIRÓS, 2002, p. 537).
}

Ao descrever o processo de modernização japonesa, Eça não parece ser um entusiasta do momento histórico da "Terra do Sol Nascente". Aqui, nosso autor parece se aproximar da visão negativa que definiu como de um "europeu mediano", por the parecer a nova civilização japonesa "macaqueada" (QUEIRÓS, 2002, p. 529). Neste trecho, ao se referir ao novo Japão como uma civilização "comprada por preços ruinosos num 'armazém de civilizações feitas"', demonstra, até certo ponto, um olhar próximo ao dos japonistas que viam e condenavam a artificialidade do Japão nascente. Embora não lamente o "Japão puro que se perde", Eça também não vê como positiva a modernização nipônica. Prossegue, então, seu raciocínio tratando diretamente do imperador Meiji:

Nada representa ou deve representar melhor um estado do que o seu chefe - e ainda há pouco eu considerava duas estampas que pintam com um relevo desolador (para o artista) a transformação do velho em novo Japão. Numa é o micado, ainda imperador omnipotente e 
hierático, meio homem, meio deus, alçado no seu trono, que mais parece altar, todo envolto num manto de seda cor de palha, com uma mitra de laca branca, onde faíscam pedrarias, imóvel e de olhos baixos à maneira de um ídolo, enquanto o fumo do incenso se eleva das caçoletas, e velhos daimios feudais e samurais magníficos, vestidos de brocados, de bronzes dourados, os dois sabres na cintura, as duas antenas de ouro tremendo no elmo, se prostram ante a majestade do Filho do Sol, tocam com a fronte as finas esteiras claras, juncadas de flores de nassari. Na outra estampa, de cores vivas, é ainda o mesmo micado, anos depois, mais pequeno e como diminuído, com uma farda vermelha de general inglês que lhe faz rugas no sovaco, um capacete branco de general prussiano que lhe tomba para os olhos, umas calças azuis de general francês que lhe fogem dos tornozelos, sentado de esguelha numa poltrona, dentro de uma estação de caminho de ferro, enquanto em redor se agitam funcionámos constitucionais, de chapéus de bico, de chapéus altos, de chapéuscoco, apelintrados e contrafeitos, e ao longe uma locomotiva fumega e vai partir por sob um arco de lona que ostenta este lema estupendo: "Viva a constituição!" Este é o Japão novo. E lúgubre. (QUEIRÓS, 2002, p. 537-538)

Aqui, aparece a ratificação das imagens depreendidas anteriormente através da ironia do "novo" imperador. Ao definir como "lúgubre" a figura europeizada do imperador, metonímia de todo império japonês, nosso autor apenas fortalece a imagem do Japão de Meiji como uma civilização artificial e pouco original.

Em texto intitulado "A França e o Sião", publicado no mesmo jornal brasileiro, mas datado de 1893, isto é, um ano antes de "Chineses e Japoneses", Eça também analisa uma figura real. Neste texto, em que parte de um breve conflito bélico envolvendo a França e o Reino do Sião ${ }^{11}$ para debater sobre o imperialismo e o colonialismo francês e inglês, nosso autor ironiza a figura real siamesa, o Rei Chulalonkorn. Cito:

O Sião é um reino do Extremo Oriente, muito rico e, portanto, muito apetecível. Tem um rei bastante curioso, segundo se depreende da sua fotografia, porque da cinta para cima anda vestido à chinesa, e da cinta para baixo à Luís XV! E todo o reino, ao que dizem, participa assim da Ásia e da Europa. As suas fortalezas oferecem uma arquitectura fantasista de mágica - e estão armadas de canhões Krupp (QUEIRÓS, 2002, p. 368).

A diferença de tratamento dado ao imperador Meiji e ao rei Chulalonkorn é pouca. Embora este seja mais fortemente ironizado, o "novo" imperador japonês não lhe parece menos burlesco. Então, finaliza sua reflexão sobre o império japonês:

Mas é forte - porque, com os nossos horrendos chapéus de bico e as nossas pantalonas agaloadas, adoptou também os nossos couraçados, as espingardas Lebel, as metralhadoras, toda a nossa organização e ciência militar. E, como não lhe falta a inteligência destra para aplicar os nossos princípios e usar o nosso material, e como os seus oficiais são educados nas escolas, nos arsenais, nos campos de manobras da Europa, em breve o Japão pitoresco se tornou o Japão formidável, e, apesar de as fardas mal feitas lhe darem um ar xexé de Entrudo, ficou sendo a grande potência do Extremo Oriente (QUEIRÓS, 2002, p. 538).

11. Atual Tailândia. 
Neste trecho final, Eça volta a enxergar respeitosamente o Japão. Embora não seja defensor da modernização japonesa, demonstra grande respeito a esta nação que se forma, principalmente, ao se aliar a inteligência - que nosso autor considera uma qualidade do povo nipônico - com a tecnologia bélica europeia. Adiante, mais uma vez, trata da rivalidade entre China e Japão, ao tentar, mais uma vez, levar a seus leitores como estas nações se enxergavam.

A China observou com indizível nojo esta revolução social do Japão - mas também com uma vaga inquietação. Os homens que aboliam o mais santo dos cultos, o culto do passado, que se enfardelavam com a rabona estrangeira, que abandonavam as suas festas religiosas para aplaudir em casinos alumiados a gás as cançonetas torpes de Marselha, eram, sem dúvida, vis: mas os seus portos estavam cheios de couraçados, os seus arsenais de armamentos, um saber novo penetrara na sua educação, e podiam, portanto, apesar de ignóbeis, ser perigosos. A manhosa e forte civilização dos "diabos europeus" convertera-os numa grande potência asiática, comunicando-lhes as suas manhas e a sua força - convinha, portanto, adquirir também essa força e essas manhas para que o Império do Meio não fosse sobrepujado pelo pequeno Império do Sol Nascente, uma vez que está desgraçadamente provado que a espingarda Lebel mata melhor que a elegante e venerável flecha dos avós.

Foi, portanto, o Japão que forçou sobretudo a China a entrar, bem a seu pesar, na imitação europeia - e este passo humilhante, tão contrário a todos os seus sentimentos sociais, políticos e religiosos, a que a China era impedida pela indecente europeização do vizinho Japão, mais irritou os mandarins contra o Governo, agora constitucional, do micado. O velho Japão já era antipático à China - o novo Japão, apetrechado à europeia, com gás e com telefones, tornou-se-lhe intoleravelmente odioso. A própria questão da Coreia, tão antiga entre os dois povos, se complicou, se azedou com esta questão recente e singular das inovações ocidentais. Em Seul, na corte do pobre rei da Coreia, as influências chinesa e japonesa, em hostilidade latente desde longos anos, combateram-se agora, nestes derradeiros tempos, acerca dessas formas de civilização que o Japão, com o zelo dos novos convertidos, tentava introduzir na Coreia, e que a China se esforçava em repelir, com rancor. Assim o Japão levava o fraco e aturdido Governo coreense a criar uma escola militar de tipo europeu - e imediatamente a China conseguia a sua supressão. Depois, foi um caminho de ferro, a que a influência japonesa assentara os primeiros rails - e que a influência chinesa logo tortuosamente embargou e por fim destruiu (QUEIRÓS, 2002, p. 538-539).

A partir deste trecho, Eça passa a tratar da iminente invasão japonesa à capital chinesa, Pequim, prevendo que a derrota chinesa na guerra levaria a uma grande quantidade de pessoas deixando o território chinês em busca de trabalho. Assim, o autor de O Primo Basílio chega ao ponto principal de seu texto, a imigração chinesa, mas que, por não ser nosso foco neste trabalho, não adentraremos ${ }^{12}$.

Outro texto da Gazeta de Notícias apresenta uma rápida referência ao Japão. Estamos falando de "A Propósito da Doutrina Monroe e do Nativismo", publicado também em cinco partes entre março e abril de 1896. Este texto tem como tema principal a política americana aplicada pelo presidente norte-americano James Monroe cuja frase que a resume é "A América para os americanos". Uma política, teoricamente, contra

12. Para uma análise de trechos e questões deste texto aqui não abordadas, cf. VANZELLI, 2013. 
a colonização europeia na América. Como consequência dessa política adotada no primeiro quartel do século XIX, Eça discute a noção de nativismo, ou seja, a política de favorecer habitantes nativos de uma nação em detrimento a estrangeiros e imigrantes. O escritor diz que o nativismo é um sentimento que nasceu na China. Eça afirma que, no caso chinês, havia uma justificativa para existência desse sentimento, uma vez que, diferentemente dos Estados Unidos que foi uma colônia britânica, a China sempre foi habitada por chineses. Então, o cônsul português se refere ao Japão:

\footnotetext{
Não há todavia nenhuma originalidade nesta doutrina do nativismo. Nem ela nasceu na América. Mais de dois mil anos certamente são passados desde que a China a concebeu e a praticou. $\mathrm{O}$ nativismo é, com efeito, um produto chinês, adoptado durante algum tempo pelo Japão, depois por ele abandonado como caduco e caturra, e agora posto, com grande alarido, em circulação pelos povos americanos. (QUEIRÓS, 2002, p. 594).
}

Mais uma vez, o Japão aparece em comparação com a China. Novamente, Eça parece conhecer as diferenças que envolvem as culturas chinesas e japonesas, mesmo que suas informações venham de livros, sem uma experiência in loco. Este trecho ainda reforça a imagem do Japão como um país "adaptador". Se em "Chineses e Japoneses" Eça tratava do Japão que adaptava a tecnologia e os valores euro-americanos, agora, em "A Propósito da Doutrina Monroe e do Nativismo", nosso autor mostra um Japão que adaptou os valores chineses.

Se bem observado, sempre que a civilização chinesa e a japonesa são comparadas, a China aparece como uma nação mais "tradicionalista", mais fechada à sua relação com o estrangeiro. Em contrapartida, o japonês é representado como o povo que importa ideias e tecnologia e os adapta à sua realidade. Deste modo, o Japão é visto como menos preso a seus valores tradicionais e mais aberto ao que vem do exterior.

\section{Conclusão}

Através da análise de excertos de alguns textos queirosianos, principalmente do romance Os Maias e da crônica "Chineses e Japoneses", é possível ver as diversas formas em que a "Terra do Sol Nascente" é tratada pelo autor de $O$ Crime do Padre Amaro. Verifica-se que não se pode encaixar Eça como um adepto da estética japonista, embora demonstre lucidez da maneira como esta tendência se refletia na sociedade europeia do final do século XIX. O olhar de Eça ao Japão é, principalmente, respeitoso, reconhecendo que "por trás [...] dos guarda-sóis de papel, e das caturrices, e de todo o exotismo, existam sólidas instituições sociais e domésticas, uma velha e copiosa literatura, uma intensa vida moral, fecundos métodos de trabalho, energias ignoradas" (QUEIRÓS, 2002, p. 529). Também é de se destacar que Eça, nascido e criado na Europa, soube se informar e procurou transmitir a seus leitores as particularidades, em sua visão, da civilização japonesa e das demais civilizações asiáticas. Ao recordarmos que Eça nunca esteve no Extremo Oriente e seu interesse por estas culturas não foi seu 
principal objeto de reflexão ao longo de sua carreira, acreditamos que devemos ressaltar este aspecto de um autor que não optou por simplesmente perpetuar estereótipos. Ao contrário, como vimos, o escritor ironiza estes mesmos "lugares-comuns" presentes no imaginário do velho continente.

O autor de Os Maias, no entanto, se aproxima, de um lado, dos escritores japonistas e, de outro, de seus concidadãos ao enxergar o Japão resultante da modernização ocorrida durante a era Meiji como uma civilização "copiada" ou "artificial".

Assim, encerramos nosso percurso, afirmando que, ao se analisar as representações do Japão de Eça de Queirós, encontra-se uma visão de certo modo ponderada, em que se verifica a consciência das várias formas (entusiasmadas e preconceituosas) que o Japão era enxergado pela sociedade europeia do fin-de-siècle, mas que não se encaixa com perfeição a nenhuma dessas "chaves de leitura". Deste modo, nos parece claro que o Japão queirosiano é, sobretudo, para sua época, original. Embora tenha sido aparecido em poucos textos, não foi, em momento algum, mal refletido.

\section{Referências Bibliográficas}

ARAÚJO, Gabriel Antunes. A Língua Portuguesa no Japão: um panorama. In: ARAÚJO, Gabriel Antunes e AIRES, Pedro (org.). A Língua Portuguesa no Japão. São Paulo: Paulistana, p. 9-24, 2008.

CASTElO-BRANCO, Miguel. Portugueses no Sião, China e Japão. In: Portugal. Biblioteca Nacional. Os Portugueses e o Oriente: Sião, China e Japão (18401940): mostra bibliográfica. Lisboa: BN, p. 57-82, 2004.

DANTAS, Luiz. Apresentação à primeira edição. In: AZEVEDO, Aluísio. O Japão. Rio de Janeiro: Fundação Biblioteca Nacional, p. 163-220, 2010.

FIGUEIREDO, Fidelino de. O Homem que trocou a sua alma. In: MORAES, Wenceslau de. Dai Nippon. Rio de Janeiro: Nórdica, p. 13-38, 1993.

GROSSEGESSE, Orlando. O fantasma do chinês deschinesado. In: QUEIRÓS, Eça de.

Chineses e Japoneses. Lisboa: Fundação Oriente, p. 7-26, 1997

HORIGOSHI, Érika. Para entender o Japão: aspectos da cultura japonesa em textos de Wenceslau de Moraes. Dissertação (mestrado em Letras). Faculdade de Filosofia Letras e Ciências Humanas, Universidade de São Paulo, São Paulo, 2012.

KUNIYOSHI, Celina. Imagens do Japão. Uma utopia de viajantes. São Paulo: Estação Liberdade e FAPESP, 1998.

LIMA, Fábio. Um Japão que se perdeu. In: AZEVEDO, Aluísio. O Japão. Rio de Janeiro: Fundação Biblioteca Nacional, p. 7-22, 2010.

LOURENÇO, Eduardo. O Labirinto da Saudade. $6^{\text {a }}$ ed. Lisboa: Gradiva, 2009. 
MAGALHÃES, José Calvet de. Eça de Queirós, cônsul e escritor. In: Revista Camões, $n^{\circ}$. 9-10. Lisboa: Instituto Camões, p. 8-22, 2000.

MINÉ, Elza. Páginas Flutuantes - Eça de Queirós e o jornalismo do século XIX. Cotia: Ateliê Editorial, 2000.

QUEIRÓS, Eça de. Obras Completas de Eça de Queiróz. 3 vols. Porto: Lello \& Irmão Editores, 1958.

QUEIRÓS, Eça de. 13 de Agosto de 1893. In: MINÉ, Elza e CAVALCANTE, Neuma (org.). Edição Crítica das Obras de Eça de Queirós. Textos de Imprensa IV (da Gazeta de Notícias). Lisboa: Imprensa Nacional-Casa da Moeda, p. 365-370, 2002.

QUEIRÓS, Eça de. Chineses e Japoneses. In: MINÉ, Elza e CAVALCANTE, Neuma (org.). Edição Crítica das Obras de Eça de Queirós. Textos de Imprensa IV (da Gazeta de Notícias). Lisboa: Imprensa Nacional-Casa da Moeda, p. 527-546, 2002.

QUEIRÓS, Eça de. A Propósito da Doutrina Monroe e do Nativismo. In: MINÉ, Elza e CAVALCANTE, Neuma (org.). Edição Crítica das Obras de Eça de Queirós. Textos de Imprensa IV (da Gazeta de Notícias). Lisboa: Imprensa NacionalCasa da Moeda, p. 585-605, 2002.

SPENGLER, Eusébio Leal. Eça em Havana. In: Revista Camões, nº 9-10. Lisboa: Instituto Camões, p. 24-26, 2000.

VANZELLI, José Carvalho. Eça de Queirós e o Extremo Oriente. 2013. Dissertação (Mestrado em Letras) Faculdade de Filosofia Letras e Ciências Humanas, Universidade de São Paulo, São Paulo, 2013. 